\title{
Potensi Pengembangan Kawasan Berbasis Transit Oriented Development di Sekitar Titik Transit Kabupaten Bogor
}

\author{
The Potential of Transit Oriented Development at Transit Nodes in Bogor Regency
}

\author{
Nedalia Wilza $^{{ }^{*}}$, Ernan Rustiadi ${ }^{2}$ \& Janthy Trilusianthy Hidajat ${ }^{3}$ \\ ${ }^{1}$ Program Studi Ilmu Perencanaan Wilayah, Sekolah Pascasarjana, Institut Pertanian Bogor, Kampus IPB \\ Dramaga, Bogor 16680, Indonesia; ${ }^{2}$ Departemen Ilmu Tanah dan Sumberdaya Lahan, Fakultas Pertanian, \\ Institut Pertanian Bogor, Kampus IPB Dramaga, Bogor 16680, Indonesia; ${ }^{3}$ Program Studi Perencanaan \\ Wilayah dan Kota, Fakultas Teknik, Universitas Pakuan, Jalan Pakuan Bogor 16143, Indonesia; \\ "Penulis korespondensi.e-mail: nedalia.wz@gmail.com \\ (Diterima: 4 Mei 2021; Disetujui: 15 Juni 2021)
}

\begin{abstract}
The high number of commuters in Bogor Regency has triggered the development of settlements at transit areas. In addition, Bogor Regency is also connected to rail-based mass public transportation in the Jabodetabek area which supports the mobility of its population. This study aims to identify the suitability of a transit area to be developed with Transit Oriented Development (TOD) concept. The research location is among the transit areas of two intercity train stations and seven existing urban commuter line train stations in Bogor Regency. Observations focused on the area in a radius of 800 meters from the station which is assessed as the maximum distance a person can walk for 15 minutes. Potential locations are determined by the AHP (Analytical Hierarchy Process) and TOPSIS (Technique for Order Preference by Similarity to Ideal Solution) method on several variables that form the ideal TOD. The variables observed include aspects of transportation and aspects of land use which are derived into several indicators. Based on the research, it was found that the most potential area to be developed with the TOD concept is the transit area of Cibinong station, followed by transit areas of Bojonggede station, Citayam station, and Cilebut station. Meanwhile, transit areas of Parung Panjang station and Tenjo station have medium potential, and transit areas Maseng Station and Cigombong Station are not potential.
\end{abstract}

Keywords: settlement, station, TOD, transit area, transportation

\begin{abstract}
ABSTRAK
Tingginya jumlah komuter di Kabupaten Bogor memicu perkembangan permukiman di sekitar titik transit. Selain itu, Kabupaten Bogor juga terkoneksi dengan angkutan umum massal berbasis rel dalam kawasan Jabodetabek yang mendukung mobilitas penduduknya. Penelitian ini bertujuan untuk melihat tingkat kesesuaian suatu kawasan transit untuk dikembangkan dengan konsep Transit Oriented Development (TOD). Lokasi penelitian adalah pada kawasan sekitar stasiun yang meliputi dua stasiun kereta api antar kota dan tujuh stasiun kereta api perkotaan eksisting jenis commuter line di Kabupaten Bogor. Pengamatan difokuskan kawasan yang berada pada radius 800 meter dari stasiun yang dinilai sebagai jarak maksimal seseorang dapat berjalan kaki selama 15 menit. Lokasi potensial ditentukan dengan metode Analytical Hierarchy Process (AHP) dan Technique for Order Preference by Similarity to Ideal Solution (TOPSIS) terhadap beberapa variabel pembentuk kawasan TOD yang ideal. Variabel yang diamati meliputi aspek
\end{abstract}


transportasi dan aspek penggunaan lahan yang diturunkan menjadi beberapa indikator. Berdasarkan penelitian ditemui bahwa kawasan yang paling berpotensi dikembangkan dengan konsep TOD adalah kawasan transit Stasiun Cibinong, diikuti oleh kawasan transit Stasiun Bojonggede, Stasiun Citayam, dan Stasiun Cilebut. Sementara itu kawasan transit Stasiun Parung Panjang dan Stasiun Tenjo memiliki potensi sedang dan kawasan transit Stasiun Maseng serta Stasiun Cigombong tidak potensial.

Kata kunci: kawasan transit, permukiman, stasiun, TOD, transportasi

\section{PENDAHULUAN}

Sebagai bagian dari Kawasan Strategis Nasional (KSN) Perkotaan Jabodetabekpunjur, Kabupaten Bogor berperan sebagai salah satu kota satelit menjadi bagian pengembangan sistem pusat permukiman dan pengintegrasian sistem jaringan prasarana transportasi kawasan (Peraturan Presiden Nomor 60 Tahun 2020). Perannya sebagai hinterland dan letak wilayah yang berbatasan langsung dengan ibukota menjadikan Kabupaten Bogor sangat berpotensi merasakan backwash effect maupun spread effect dari pembangunan dan pertumbuhan ekonomi di Jakarta.

Pesatnya laju pertumbuhan penduduk di Kabupaten Bogor yaitu sebesar 4.6\% per tahun pada tahun 2011 hingga 2019 (BPS Kabupaten Bogor 2012-2020) dan tingginya jumlah komuter yang berkegiatan utama di luar Kabupaten Bogor yaitu sebesar 408,874 orang/hari (Statistik Komuter Jabodetabek 2019), akan berimplikasi pada peningkatan luas lahan terbangun di Kabupaten Bogor. Kebutuhan akan kemudahan aksesibilitas dan adanya bangkitan aktivitas ekonomi akibat kegiatan transit menjadikan kawasan sekitar titik transit berpotensi berkembang menjadi kawasan permukiman (Priadmaja et al., 2017). Ditambah dengan semakin sempitnya lahan di ibukota yang menyebabkan para komuter yang bekerja di ibukota mencari hunian di pinggiran untuk suasana yang lebih nyaman dan harga yang lebih terjangkau (Roy et al., 2017). Tersedianya moda angkutan umum massal yang terkoneksi dalam lingkup kawasan Jabodetabek juga menjadi salah satu aspek yang mendukung mobilitas komuter dari daerah pinggiran ke ibukota.
Pesatnya pertumbuhan permukiman dan tingginya jumlah kendaraan bermotor di Kabupaten Bogor yaitu sebesar 1,608,455 kendaraan bermotor pada tahun 2018 berdampak pada peningkatan jumlah pergerakan atau mobilitas penduduk dalam rangka pemenuhan kebutuhan hidupnya (BPS Kabupaten Bogor, 2020; Purwanto, 2015). Dalam perencanaan wilayah aspek transportasi memang berkaitan erat dengan tata guna lahan sebagai satu land use transport system (Arif \& Manullang, 2017). Besar kecilnya perubahan penggunaan lahan akan berdampak pada lalu lintas di sekitarnya (Sumajouw et al., 2013). Choerunnisa dan Dirgahayani (2020) menemukan adanya hubungan positif antara penumpang SAUM dengan guna lahan yang diidentifikasi dari kepadatan dan keberagaman guna lahan. Tingginya mobilitas penduduk dan rendahnya tingkat penggunaan moda transportasi publik oleh komuter (BPS, 2020) semakin menambah volume lalu lintas yang dapat memicu persoalan lalu lintas. Perkembangan wilayah ke arah pinggiran kota yang tidak diikuti oleh kesiapan perencanaan wilayah akan menyebabkan terjadinya urban sprawl, serta bangkitan kegiatan ekonomi dan pedagang informal yang tidak tertata dengan baik di sekitar titik transit.

Salah satu konsep pengembangan kawasan untuk mengatasi permasalahan urban sprawl yang dapat mendukung perwujudan pembangunan berkelanjutan adalah konsep Transit Oriented Development (TOD). Peter Calthorpe (1993) memperkenalkan konsep TOD sebagai suatu bentuk pembangunan mixed-use yang mendorong masyarakat untuk tinggal dan beraktivitas di suatu kawasan yang memiliki fasilitas transportasi umum untuk 
mengurangi penggunaan kendaraan pribadi (Calthorpe, 1993). Pada prinsipnya TOD adalah pengembangan kawasan campuran yang padat, kompak, dan terpusat yang terintegrasi dengan sistem angkutan umum massal untuk mendorong mobilitas berkelanjutan dengan pengembangan fasilitas yang mendorong pergerakan non-motorized di kawasan transit (Suzuki et al., 2013).

Penelitian ini bertujuan untuk mengetahui potensi pengembangan kawasan TOD sekitar titik transit di Kabupaten Bogor. Potensi pengembangan kawasan TOD diidentifikasi melalui pengamatan terhadap tingkat pemenuhan prasyarat TOD di sekitar titik transit. Prasyarat TOD ditentukan berdasarkan prinsip pengembangan TOD yang dikemukakan oleh para ahli di bidang TOD serta penelitian terdahulu. Menurut Peter Calthorpe (1993) kawasan TOD harus memenuhi prinsip ketersediaan titik transit (public transportation station), adanya ruang publik (public uses/spaces), adanya pusat komersial (commercial core), area permukiman (residential area), dan area sekunder (secondary area). Kemudian Cervero dan Kockelman (1997) menekankan tiga dimensi TOD (3D) yaitu density, diversity and design (Cervero \& Kockelman, 1997). Ewing dan Cervero (2010) melengkapi dimensi TOD menjadi 5D dengan menambahkan prinsip destination accessibility dan distance to transit. Lebih lanjut Institute for Transportation and Development Policy (ITDP) dalam standarnya menyebutkan bahwa TOD harus memenuhi delapan prinsip yaitu walk, cycle, connect, transit, mix, densify, compact, dan shift (ITDP, 2017).

Penelitian di Kawasan Metropolitan Bandung menganalisis potensi kawasan TOD melalui identifikasi ketersediaan pelayanan moda transportasi serta kriteria mixed use dan densitas kawasan (Widyahari \& Indradjati, 2015). Potensi pengembangan TOD di kawasan Stasiun Pasar Nguter diidentifikasi dengan variabel mobilitas, densitas, diversitas, linkage, dan intermoda pada radius 500 meter dari titik transit (Octarino, 2016). Penelitian di
Kabupaten Bekasi menggunakan kriteria guna lahan, urban design dan pembangunan, aksesibilitas dan perparkiran serta infrastruktur dan layanan jasa transit (Ruhukail \& Oktavia, 2017). Penelitian lainnya mengamati variabel densitas, guna lahan, ketersediaan jalur pejalan kaki dan pesepeda, interkoneksi jalan, parkir, dan ruang terbuka dalam melihat kesesuaian konsep TOD di kawasan transit Kota Surakarta dengan mengacu pada ketentuan dari TCRP (Transit Cooperative Research Program) 2002, TCRPC (Treasure Coast Regional Planning Council) 2012 dan ITDP 2015 (Jati et al., 2017). Arsyad \& Handayeni (2018) mengamati potensi TOD di kawasan transit blok $\mathrm{M}$ dengan menganalisis variabel densitas, diversitas, dan desain (Arsyad \& Handayeni, 2018). Dirgahayani \& Choerunnisa (2019) mengembangkan metodologi dalam mengevaluasi kelayakan TOD di lingkungan terbangun di Jakarta dan Bandung dengan menggunakan kriteria dan indikator berdasarkan prinsip 5D (Calthorpe, 1993; Ewing \& Cervero, 2010). Variabel dari teori Cervero (1997) dan ITDP digunakan oleh Ayuningtias \& Karmilah (2019) dalam penelitian potensi TOD di Kota Surabaya, Kota Bandung dan Kota Jakarta. Namun penelitian ini belum fokus pada titik transitnya melainkan mengamati dalam lingkup wilayah administrasi secara keseluruhan (Ayuningtias \& Karmilah, 2019). Penelitian lainnya di Malaysia, mencoba melihat potensi pengembangan TOD dengan variabel yang lebih terukur di 17 stasiun. Variabel yang diamati dalam radius $400 \mathrm{~m}$ meliputi tutupan lahan, ketersediaan lahan, potensi gentrifikasi, densitas, dan diversitas (Najib et al., 2020).

\section{METODOLOGI}

Tingkat potensi pengembangan konsep TOD diidentifikasi dengan melakukan pengamatan terhadap pemenuhan prasyarat TOD di dua stasiun kereta api antar kota yang meliputi Stasiun Maseng dan Cigombong, serta tujuh stasiun kereta api perkotaan jenis commuterline (KRL) yang meliputi Stasiun 
Cilebut, Bojonggede, Citayam, Cibinong, berjalan kaki dalam 15 menit. Referensi lain Nambo, Parung Panjang, dan Tenjo. Fokus juga mendefinisikan TOD pada radius 400 pengamatan adalah pada area yang berada dalam radius $800 \mathrm{~m}$ dari titik transit yang merupakan radius maksimal dari wilayah perencanaan TOD menurut Peraturan Menteri Agraria dan Tata Ruang/BPN Nomor 16 Tahun 2017. Wilayah perencanaan TOD ditentukan berdasarkan jarak maksimum seseorang dapat sampai 800 meter dari stasiun (Guerra et al., 2012). Mengingat adanya lokasi stasiun di perbatasan kabupaten maka sebagian wilayah administrasi Kota Depok dan Kabupaten Tangerang turut masuk dalam lingkup analisis. Titik stasiun lokasi penelitian dijelaskan pada Gambar 1.

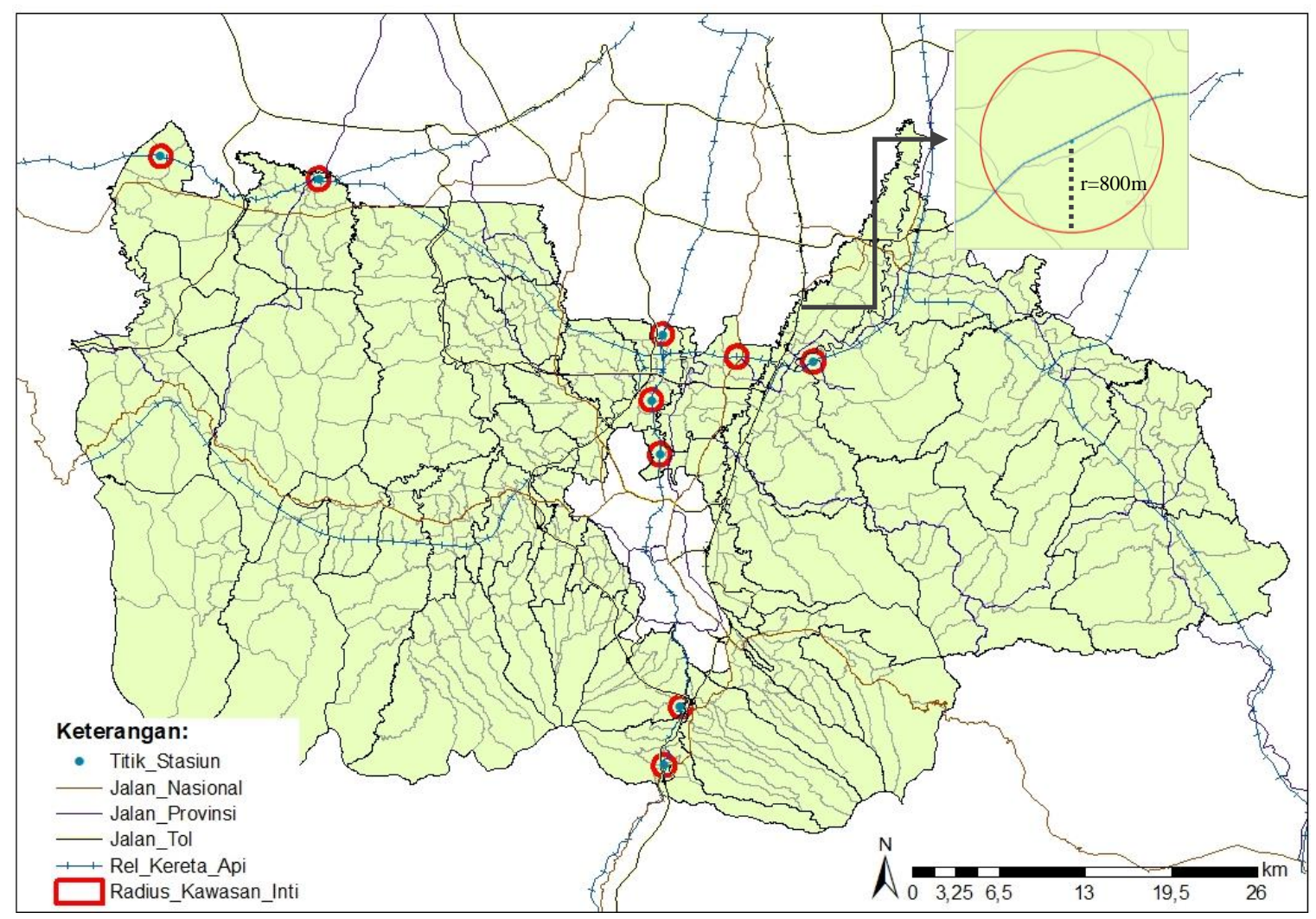

Gambar 1. Titik stasiun lokasi penelitian

\section{Variabel Analisis}

Variabel analisis ditentukan berdasarkan sintesa dari kajian teori dan penelitian terdahulu. Prinsip TOD yang dikemukakan oleh ahli kemudian dikelompokkan dan didefinisikan ke dalam bentuk variabel umum penelitian sebagaimana dijelaskan pada Tabel 1 .

Tabel 1. Penentuan variabel penelitian berdasarkan prinsip dasar TOD

\begin{tabular}{ccccc}
\hline Sumber & \multicolumn{4}{c}{ Prinsip TOD } \\
\hline Peter Calthorpe (1993) & $\begin{array}{c}\text { public transportation } \\
\text { station }\end{array}$ & $\begin{array}{c}\text { residential } \\
\text { area }\end{array}$ & $\begin{array}{c}\text { commercial } \\
\text { core }\end{array}$ & $\begin{array}{c}\text { public } \\
\text { uses/spaces }\end{array}$ \\
\hline TOD Standard (ITDP) 2017 & transit & $\begin{array}{c}\text { compact, } \\
\text { densify }\end{array}$ & mix & $\begin{array}{c}\text { walk, cycle } \\
\text { connect, shift }\end{array}$ \\
\hline Cervero dan Kockelman (1997) & & density & diversity & design \\
\hline $\begin{array}{c}\text { TCRP (Transit Cooperative } \\
\text { Research Program) 2002 }\end{array}$ & density & $\begin{array}{c}\text { land-use } \\
\text { mixes }\end{array}$ & $\begin{array}{c}\text { design } \\
\text { quality }\end{array}$
\end{tabular}




\begin{tabular}{|c|c|c|c|c|}
\hline Sumber & \multicolumn{4}{|c|}{ Prinsip TOD } \\
\hline Ewing \& Cervero, 2010 & $\begin{array}{c}\text { destination } \\
\text { accessibility, } \\
\text { distance to transit }\end{array}$ & density & diversity & design \\
\hline $\begin{array}{l}\text { Treasure Coast Regional } \\
\text { Planning Council) } 2012\end{array}$ & mobility & $\begin{array}{l}\text { moderate- } \\
\text { high intensity } \\
\text { and density }\end{array}$ & mixed uses & $\begin{array}{c}\text { walkability, } \\
\text { connectivity, } \\
\text { urban form }\end{array}$ \\
\hline Variabel penelitian & Transit & Density & Diversity & Design \\
\hline
\end{tabular}

Penelitian terdahulu yang mengamati berbeda-beda. Setiap kriteria kemudian tingkat potensi pengembangan TOD di diterjemahkan ke dalam variabel penelitian beberapa daerah menggunakan kriteria yang sebagaimana dijelaskan pada Tabel 2.

Tabel 2. Kriteria penentuan potensi TOD dalam penelitian terdahulu

\begin{tabular}{|c|c|c|c|c|c|}
\hline \multirow{2}{*}{ Peneliti } & \multicolumn{5}{|c|}{ Variabel pengamatan potensi TOD } \\
\hline & Transit & Density & Diversity & Design & Lainnya \\
\hline $\begin{array}{l}\text { Widyahari \& } \\
\text { Indradjati, } 2015\end{array}$ & $\begin{array}{l}\text { ketersediaan } \\
\text { moda } \\
\text { transportasi }\end{array}$ & $\begin{array}{l}\text { densitas } \\
\text { bangunan }\end{array}$ & $\begin{array}{c}\text { percampuran } \\
\text { land-use }\end{array}$ & & $\begin{array}{c}\text { karakteristik } \\
\text { retail }\end{array}$ \\
\hline Octarino, 2016 & $\begin{array}{c}\text { integrasi } \\
\text { intermoda }\end{array}$ & $\begin{array}{c}\text { kepadatan } \\
\text { bangunan dan } \\
\text { populasi } \\
\end{array}$ & diversitas & linkage & $\begin{array}{l}\text { mobilitas } \\
\text { penduduk }\end{array}$ \\
\hline $\begin{array}{l}\text { Ruhukail \& } \\
\text { Oktavia, 2017 }\end{array}$ & $\begin{array}{c}\text { infrastruktur } \\
\text { dan layanan } \\
\text { jasa transit }\end{array}$ & $\begin{array}{c}\text { densitas } \\
\text { bangunan dan } \\
\text { employment }\end{array}$ & $\begin{array}{l}\text { guna lahan } \\
\text { campuran }\end{array}$ & $\begin{array}{c}\text { aksesibilitas } \\
\text { dan } \\
\text { perparkiran } \\
\end{array}$ & $\begin{array}{c}\text { ketersediaan } \\
\text { lahan, urban } \\
\text { design } \\
\end{array}$ \\
\hline Jati et al., 2017 & & $\begin{array}{c}\text { kepadatan } \\
\text { kawasan }\end{array}$ & $\begin{array}{l}\text { guna lahan } \\
\text { campuran }\end{array}$ & $\begin{array}{l}\text { jalur pejalan } \\
\text { kaki, pesepeda, } \\
\text { parkir, ruang } \\
\text { terbuka }\end{array}$ & $\begin{array}{c}\text { interkoneksi } \\
\text { jalan }\end{array}$ \\
\hline $\begin{array}{l}\text { Arsyad \& } \\
\text { Handayeni, } 2018\end{array}$ & & densitas & diversitas & desain & \\
\hline $\begin{array}{l}\text { Dirgahayani \& } \\
\text { Choerunnisa, } 2019\end{array}$ & $\begin{array}{c}\text { destination } \\
\text { accessibility, } \\
\text { distance to } \\
\text { transit }\end{array}$ & $\begin{array}{c}\text { building } \\
\text { density and } \\
\text { intensity level }\end{array}$ & $\begin{array}{l}\text { land use } \\
\text { diversity }\end{array}$ & $\begin{array}{c}\text { walkability, } \\
\text { support bicycle } \\
\text { uses, park }\end{array}$ & \\
\hline $\begin{array}{l}\text { Ayuningtias \& } \\
\text { Karmilah, } 2019\end{array}$ & $\begin{array}{l}\text { ketersediaan } \\
\text { moda } \\
\text { transportasi }\end{array}$ & $\begin{array}{c}\text { kepadatan } \\
\text { kawasan dan } \\
\text { bangunan }\end{array}$ & $\begin{array}{l}\text { persentase } \\
\text { land-use }\end{array}$ & $\begin{array}{c}\text { fasilitas difabel } \\
\text { dan pejalan } \\
\text { kaki }\end{array}$ & \\
\hline Najib et al., 2020 & & $\begin{array}{c}\text { area } \\
\text { coverage, } \\
\text { density }\end{array}$ & diversity & & $\begin{array}{c}\text { land availability } \\
\text { gentrification } \\
\text { potential }\end{array}$ \\
\hline
\end{tabular}

Berdasarkan landasan teori dan kajian dari penelitian terdahulu ditetapkan indikator untuk setiap variabel penelitian dengan menambahkan aspek kebijakan tata ruang yang dinilai sebagai variabel penting dalam pembangunan kawasan TOD. Indikator dipilih yang bersifat kuantitatif sehingga lebih mudah diberikan penilaian. Setiap indikator diberi skor 0 sampai 3 sesuai dengan persyaratan tertentu dari setiap kategori. Variabel dan indikator penelitian yang digunakan serta ketentuan penilaian dijelaskan pada Tabel 3 dan Tabel 4. 
Tabel 3. Variabel dan indikator penelitian

\begin{tabular}{clc}
\hline Variabel penelitian & \multicolumn{1}{c}{ Indikator } & Kriteria \\
\hline \multirow{2}{*}{ 1. Aspek transportasi (transit) } & - Jumlah moda transportasi & $\mathrm{C} 1$ \\
& - Frekuensi layanan transit (headway) & $\mathrm{C} 2$ \\
\hline
\end{tabular}

2. Penggunaan lahan

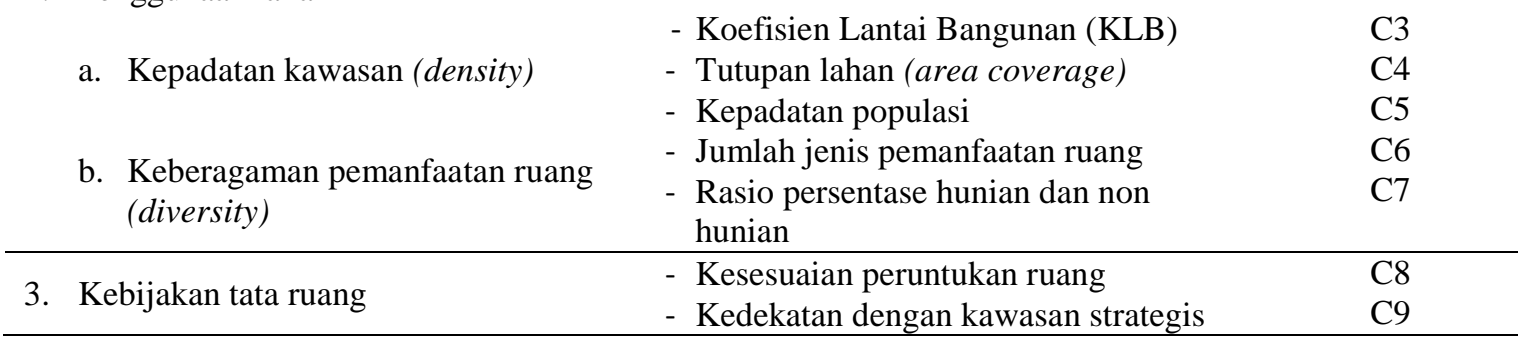

Tabel 4. Skor dan sumber data variabel analisis lokasi potensial Transit Oriented Development (TOD)

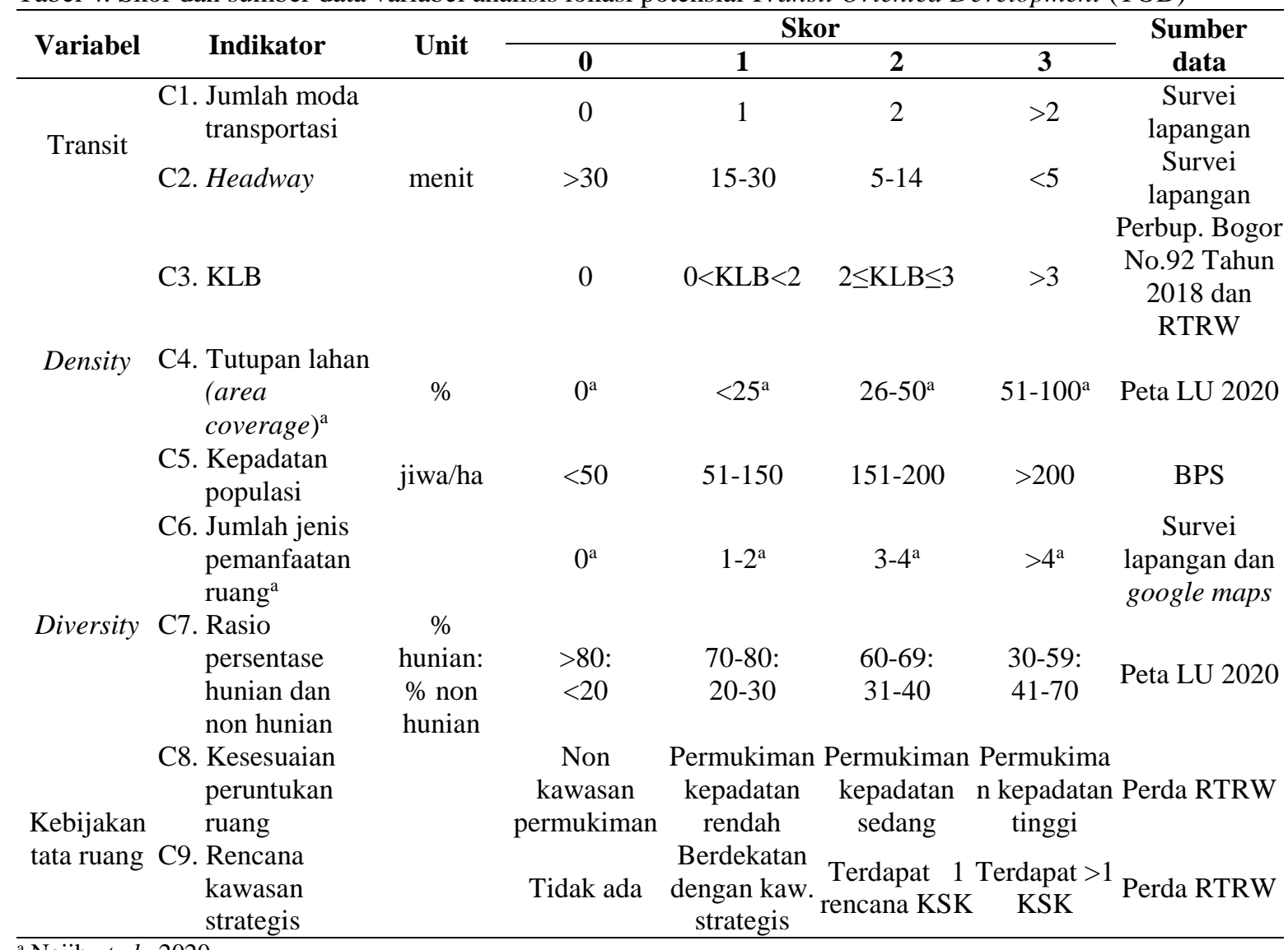

${ }^{a}$ Najib et al., 2020.

Skor untuk indikator jumlah moda $(\mathrm{C} 1)$, headway $(\mathrm{C} 2)$, serta rasio hunian dan non hunian (C7) ditentukan berdasarkan sintesa dari muatan Peraturan Menteri Agraria dan Tata Ruang/Kepala BPN Nomor 16 Tahun 2017 tentang Pedoman Pengembangan Kawasan Berorientasi Transit. Jika dilihat dari lokasi maupun karakteristik kawasan transit secara umum, maka tipe TOD yang dapat diterapkan saat ini adalah tipologi TOD-Lingkungan. Hal ini disebabkan karena kawasan transit berlokasi di daerah dengan fungsi pelayanan berskala lingkungan ataupun kawasan perkotaan dalam kabupaten yang ditetapkan sebagai pusat kegiatan. Sehingga asumsi yang digunakan dalam menetapkan skor adalah kawasan transit minimal dapat memenuhi persyaratan dari tipologi kawasan TOD-Lingkungan, kecuali untuk indikator headway karena intensitas perjalanan kereta di Kabupaten Bogor cukup tinggi. Tanpa menutup kemungkinan adanya perkembangan kawasan ke arah tipologi TOD- 
Kota. Kawasan transit yang memenuhi persyaratan minimal jumlah moda transportasi di kawasan TOD diberi skor 2 dengan asumsi dapat dikembangkan sebagai TOD-Lingkungan, sedangkan skor 3 diberikan jika kawasan transit memiliki lebih dari satu feeder dengan asumsi semakin banyak moda maka semakin besar peluang untuk dapat dikembangkan menjadi TOD dengan tipologi yang lebih tinggi. Skor C2 tertinggi diberikan untuk kawasan transit yang memenuhi persyaratan headway TODKota. Skor C7 tertinggi diberikan untuk kawasan transit yang memenuhi persyaratan sebagai TOD-Lingkungan. Skor indikator KLB (C3) tertinggi ditentukan dengan mengacu pada Peraturan Bupati Bogor Nomor 92 Tahun 2018 tentang Petunjuk Teknis Ketentuan Umum Peraturan Zonasi Pemanfaatan Ruang di Kabupaten Bogor, dimana KLB maksimum di kawasan permukiman kepadatan tinggi menjadi dasar untuk skor tertinggi. Nilai KLB maksimum ditentukan berdasarkan jenis peruntukan ruang yang paling dominan. Skor indikator kepadatan populasi (C5) mengacu pada Peraturan Menteri Pekerjaan Umum dan Perumahan Rakyat Nomor 2 Tahun 2016 tentang Peningkatan Kualitas terhadap Perumahan Kumuh dan Permukiman Kumuh dimana nilai kepadatan populasi pada permukiman kepadatan tinggi diberi skor 3 . Skor tertinggi untuk indikator kesesuaian peruntukan ruang (C8) diberikan pada peruntukan kawasan permukiman perkotaan kepadatan tinggi yang dinilai paling relevan dikembangkan dengan konsep TOD. Dan rencana kawasan strategis (C9) juga dinilai berkorelasi positif dengan skor, karena prioritas pembangunan di kawasan strategis dapat membantu mewujudkan percepatan pembangunan TOD. Data peruntukkan ruang dan lokasi kawasan strategis mengacu pada muatan RTRW Kabupaten Bogor.

\section{Metode AHP-TOPSIS}

Tingkat prioritas lokasi potensial TOD dirumuskan melalui kombinasi dari metode AHP (Analytical Hierarchy Process) dan TOPSIS (Technique for Order Preference by
Similarity to Ideal Solution). Metode AHP digunakan untuk menentukan bobot dari empat variabel penelitian yang meliputi variabel transit, density, diversity, dan kebijakan tata ruang. AHP merupakan metode sistem pendukung keputusan yang dapat menentukan bobot variabel berdasarkan perhitungan dengan cara membandingkan setiap parameter secara berpasangan dengan input utamanya adalah persepsi manusia. Metode ini dikembangkan oleh Prof. Thomas Lorie Saaty dari Wharton Business School di awal tahun 1970. Data analisis diperoleh melalui kuesioner atau wawancara dengan narasumber yang mewakili ahli perencanaan wilayah dan kota, praktisi, ahli bidang transportasi, dan komuter.

Metode TOPSIS digunakan untuk menentukan perangkingan lokasi potensial berdasarkan skor dari pemenuhan setiap indikator. Konsep dasar dalam metode TOPSIS menurut Yoon \& Hwang (1981) dalam (Balioti et al., 2018) pada prinsipnya adalah pemilihan alternatif yang memiliki jarak terdekat dari solusi ideal positif dan jarak terjauh dari solusi ideal negatif. Secara umum tahapan analisis TOPSIS adalah: (1) menyusun matriks keputusan yang dinormalisasi, (2) memberikan bobot pada matriks yang telah dinormalisasi, (3) menentukan solusi ideal positif dan solusi ideal negatif, (4) menghitung ukuran pemisahan, (5) menghitung jarak kedekatan relatif dengan solusi ideal, (6) penyusunan urutan prioritas keputusan. Data yang digunakan dalam analisis TOPSIS terdiri dari data primer hasil pengamatan langsung di kawasan transit, analisis peta landuse tahun 2020, serta kajian terhadap kebijakan penataan ruang.

\section{HASIL DAN PEMBAHASAN}

\section{Karakteristik Kawasan Transit}

\section{a. Kawasan Transit Stasiun Cilebut}

Kawasan transit Stasiun Cilebut dilayani oleh satu moda transit jarak jauh berupa kereta api perkotaan jenis commuterline dengan frekuensi pelayanan yang tinggi yaitu rata-rata 
headway 4 menit dan satu moda transit jarak dekat berupa angkutan kota. Dari sisi waktu pelayanan maupun jumlah moda, angkutan kota belum dapat menjadi feeder yang baik bagi penumpang. Namun demikian moda ini menjadi satu-satunya angkutan publik yang bisa digunakan penumpang untuk beralih ke lokasi hunian. Selain itu tersedia juga layanan ojek pangkalan dan online. Dalam RTRW peruntukan seluruh kawasan transit ini adalah sebagai permukiman perkotaan kepadatan tinggi yang memiliki KLB maksimal 4. Kepadatan bangunan dan kepadatan populasi di kawasan ini juga cenderung tinggi. Jenis pemanfaatan ruang yang ditemui di kawasan ini terdiri dari perumahan, perdagangan dan jasa, perkantoran, fasilitas pelayanan publik, serta fasilitas rekreasi dan olahraga. Lingkup kawasan dan hasil pengamatan variabel analisis dijelaskan pada Tabel 5 dan Tabel 14.

Tabel 5. Lingkup kawasan transit Stasiun Cilebut

\begin{tabular}{lcrr}
\hline \multicolumn{1}{c}{ Desa } & Kecamatan & Luas (ha) & \multicolumn{1}{c}{ \% } \\
\hline Cilebut Barat & Sukaraja & 81.8 & 42.3 \\
Cilebut Timur & Sukaraja & 80.2 & 41.5 \\
Pasirjambu & Sukaraja & 29.0 & 15.0 \\
Karadenan & Cibinong & 2.5 & 1.3 \\
\hline
\end{tabular}

\section{b. Kawasan Transit Stasiun Bojonggede}

Kawasan transit Stasiun Bojonggede dilayani oleh satu moda transit jarak jauh berupa kereta api perkotaan jenis commuterline dengan frekuensi pelayanan yang tinggi yaitu rata-rata headway 4 menit dan satu moda transit jarak dekat berupa angkutan kota. Dalam RTRW peruntukan seluruh kawasan transit ini adalah sebagai permukiman perkotaan kepadatan tinggi yang memiliki KLB maksimal 4 serta berdekatan dengan PKWp Cibinong. Kepadatan bangunan dan kepadatan populasi di kawasan ini juga cenderung tinggi. Jenis pemanfaatan ruang yang ditemui di kawasan ini terdiri dari perumahan, perdagangan dan jasa, perkantoran, fasilitas pelayanan publik, serta fasilitas rekreasi dan industri. Lingkup kawasan dan hasil pengamatan variabel analisis dijelaskan pada Tabel 6 dan Tabel 14.
Tabel 6. Lingkup kawasan transit Stasiun Bojonggede

\begin{tabular}{ccrr}
\hline Desa & Kecamatan & Luas (ha) & \multicolumn{1}{c}{$\%$} \\
\hline Kedung Waringin & Bojonggede & 141.8 & 70.5 \\
Bojonggede & Bojonggede & 57.3 & 28.5 \\
Susukan & Bojonggede & 2.0 & 1.0 \\
\hline
\end{tabular}

\section{c. Kawasan Transit Stasiun Citayam}

Kawasan transit Stasiun Citayam dilayani oleh satu moda transit jarak jauh berupa kereta api perkotaan jenis commuterline dengan frekuensi pelayanan yang tinggi yaitu rata-rata headway 4 menit dan satu moda transit jarak dekat berupa angkutan kota. Dalam RTRW peruntukan seluruh kawasan transit ini adalah sebagai permukiman perkotaan kepadatan tinggi yang memiliki KLB maksimal 4. Kepadatan bangunan dan kepadatan populasi di kawasan ini juga cenderung tinggi. Jenis pemanfaatan ruang yang ditemui di kawasan ini terdiri dari perumahan, perdagangan dan jasa, perkantoran, fasilitas pelayanan publik, dan fasilitas rekreasi. Lingkup kawasan dan hasil pengamatan variabel analisis dijelaskan pada Tabel 7 dan Tabel 14.

Tabel 7. Lingkup kawasan transit Stasiun Citayam

\begin{tabular}{cccc}
\hline Desa & Kecamatan & Luas (ha) & \% \\
\hline Rawa Panjang & Bojonggede & 69.9 & 35.4 \\
Pabuaran & Bojonggede & 40.3 & 20.4 \\
Kota Depok & 87.0 & 44.1 \\
\hline
\end{tabular}

\section{d. Kawasan Transit Stasiun Cibinong}

Kawasan transit Stasiun Cibinong dilayani oleh satu moda transit jarak jauh berupa kereta api perkotaan jenis commuterline dengan frekuensi pelayanan yang rendah yaitu rata-rata headway 52 menit dan belum tersedia moda transit jarak dekat yang melewati kawasan ini. Dalam RTRW peruntukan seluruh kawasan transit ini adalah sebagai permukiman perkotaan kepadatan tinggi yang memiliki KLB maksimal 4 dan terdapat kawasan strategis PKWp Cibinong dan PPLk Cirimekar. Kepadatan bangunan dan kepadatan populasi di kawasan ini juga cenderung tinggi. Jenis pemanfaatan ruang yang ditemui di kawasan ini terdiri dari perumahan, perdagangan dan jasa, perkantoran, fasilitas pelayanan publik, fasilitas 
rekreasi dan olahraga serta industri. Fungsi kegiatan non hunian di kawasan ini memiliki persentase tertinggi dibandingkan dengan kawasan transit lainnya, artinya prasyarat fungsi campuran di kawasan ini terpenuhi dengan baik. Lingkup kawasan dan hasil pengamatan variabel analisis dijelaskan pada Tabel 8 dan Tabel 14.

Tabel 8. Lingkup kawasan transit Stasiun Cibinong

\begin{tabular}{lcrc}
\hline Desa & Kecamatan & Luas (ha) & \% \\
\hline Pabuaran & Cibinong & 138.4 & 31.2 \\
Ciriung & Cibinong & 33.5 & 16.7 \\
Cirimekar & Cibinong & 29.2 & 14.5 \\
\hline
\end{tabular}

\section{e. Kawasan Transit Stasiun Nambo}

Kawasan transit Stasiun Nambo dilayani oleh satu moda transit jarak jauh berupa kereta api perkotaan jenis commuterline dengan frekuensi pelayanan yang rendah yaitu rata-rata headway 1 jam 50 menit dan belum tersedia moda transit jarak dekat yang melewati kawasan ini. Dalam RTRW peruntukan kawasan ini adalah sebagai kawasan industri (52.7\%), permukiman perdesaan $(25.8 \%)$, lahan basah $(21.5 \%)$, dan permukiman perkotaan kepadatan tinggi $(0.002 \%)$ Kepadatan bangunan di kawasan ini tergolong sedang dan kepadatan populasinya tergolong rendah karena sebagian besar merupakan peruntukan kawasan industri. Jenis pemanfaatan ruang yang ditemui di kawasan ini terdiri dari perumahan, perdagangan dan jasa, perkantoran, fasilitas pelayanan publik, dan industri. Lingkup kawasan dan hasil pengamatan variabel analisis dijelaskan pada Tabel 9 dan Tabel 14.

Tabel 9. Lingkup kawasan transit Stasiun Nambo

\begin{tabular}{llrr}
\multicolumn{1}{c}{ Desa } & Kecamatan & Luas (ha) & \multicolumn{1}{c}{ \% } \\
\hline Bantar Jati & Klapanunggal & 179.5 & 89.3 \\
Gunung Putri & Gunungputri & 9.4 & 4.7 \\
Nambo & Klapanunggal & 8.2 & 4.1 \\
Citeureup & Citeureup & 3.9 & 1.9 \\
\hline
\end{tabular}

\section{f. Kawasan Transit Stasiun Parung Panjang}

Kawasan transit Stasiun Parung Panjang dilayani oleh satu moda transit jarak jauh berupa kereta api perkotaan jenis commuterline dengan frekuensi pelayanan tinggi yaitu rata- rata headway 9 menit dan belum tersedia moda transit jarak dekat yang melewati stasiun. Dalam RTRW peruntukan kawasan ini adalah sebagai permukiman perkotaan kepadatan tinggi (95.8\%) dan permukiman perkotaan kepadatan sedang (4.2\%). Kepadatan bangunan di kawasan ini tergolong tinggi dan kepadatan populasinya tergolong sedang. Jenis pemanfaatan ruang yang ditemui di kawasan ini terdiri dari perumahan, perdagangan dan jasa, perkantoran, fasilitas pelayanan publik, dan fasilitas rekreasi. Lingkup kawasan dan hasil pengamatan variabel analisis dijelaskan pada Tabel 10 dan Tabel 14.

Tabel 10. Lingkup kawasan transit Stasiun Parung Panjang

\begin{tabular}{cccr}
\hline Desa & Kecamatan & Luas (ha) & \multicolumn{1}{c}{$\%$} \\
\hline Parung Panjang & Parung Panjang & 128.0 & 64.0 \\
Kabasiran & Parung Panjang & 39.9 & 19.9 \\
Cibunar & Parung Panjang & 21.3 & 10.7 \\
Kabupaten Tangerang & 10.8 & 5.4 \\
\hline
\end{tabular}

\section{g. Kawasan Transit Stasiun Tenjo}

Kawasan transit Stasiun Tenjo dilayani oleh satu moda transit jarak jauh berupa kereta api perkotaan jenis commuterline dengan frekuensi pelayanan tinggi yaitu rata-rata headway 11 menit dan belum tersedia moda transit jarak dekat yang melewati stasiun. Dalam RTRW peruntukan seluruh kawasan transit ini adalah sebagai permukiman perkotaan kepadatan tinggi yang memiliki KLB maksimal 4. Kepadatan bangunan di kawasan ini tergolong sedang dan kepadatan populasinya tergolong rendah. Jenis pemanfaatan ruang yang ditemui di kawasan ini terdiri dari perumahan, perdagangan dan jasa, perkantoran, dan fasilitas pelayanan publik. Lingkup kawasan dan hasil pengamatan variabel analisis dijelaskan pada Tabel 11 dan Tabel 14.

Tabel 11. Lingkup kawasan transit Stasiun Tenjo

\begin{tabular}{clll}
\hline Desa & Kecamatan & Luas (ha) & \% \\
\hline Parung Panjang & Parung Panjang & 128.0 & 64.0 \\
Kabasiran & Parung Panjang & 39.9 & 19.9 \\
Cibunar & Parung Panjang & 21.3 & 10.7 \\
Kabupaten Tangerang & 10.8 & 5.4 \\
\hline
\end{tabular}




\section{h. Kawasan Transit Stasiun Maseng}

Kawasan transit Stasiun Maseng dilayani oleh satu moda transit jarak jauh berupa kereta api antar kota dengan frekuensi pelayanan rendah yaitu rata-rata headway 2 jam 27 menit dan belum tersedia moda transit jarak dekat yang melewati stasiun. Dalam RTRW peruntukan kawasan ini adalah sebagai peruntukan lahan basah $(44.2 \%)$, permukiman kepadatan rendah $(34.7 \%)$, dan permukiman kepadatan tinggi $(21.1 \%)$ serta terdapat PKLp Caringin. Kepadatan bangunan dan kepadatan populasi di kawasan ini tergolong rendah. Jenis pemanfaatan ruang yang ditemui di kawasan ini terdiri dari perumahan, perdagangan dan jasa, perkantoran, fasilitas pelayanan publik, serta fasilitas rekreasi dan olahraga. Lingkup Kawasan dan hasil pengamatan variabel analisis dijelaskan pada Tabel 12 dan Tabel 14.

Tabel 12. Lingkup kawasan transit Stasiun Maseng

\begin{tabular}{lcrr}
\hline \multicolumn{1}{c}{ Desa } & Kecamatan & Luas (ha) & \multicolumn{1}{c}{$\%$} \\
\hline Warung & Cijeruk & 132.1 & 65.7 \\
Menteng & & 23.9 & 11.9 \\
Cimande Hilir & Caringin & 18.6 & 9.3 \\
Ciadeg & Cigombong & 18.5 & 9.2 \\
Caringin & Caringin & 7.9 & 3.9 \\
Cibalung & Cijeruk & & \\
\hline
\end{tabular}

\section{i. Kawasan Transit Stasiun Cigombong}

Kawasan transit Stasiun Cigombong dilayani oleh satu moda transit jarak jauh berupa kereta api antar kota dengan frekuensi pelayanan rendah yaitu rata-rata headway 2 jam 33 menit dan belum tersedia moda transit jarak dekat yang melewati stasiun. Dalam RTRW peruntukan kawasan ini adalah sebagai permukiman perkotaan kepadatan sedang (89.6\%) dan kawasan peruntukan lahan basah (5.3\%). Kepadatan bangunan di kawasan ini tergolong sedang dan kepadatan populasinya tergolong rendah. Jenis pemanfaatan ruang yang ditemui di kawasan ini terdiri dari perumahan, perdagangan dan jasa, perkantoran, fasilitas pelayanan publik, serta fasilitas rekreasi dan olahraga. Lingkup kawasan dan hasil pengamatan variabel analisis dijelaskan pada Tabel 13 dan Tabel 14.

Tabel 13. Lingkup kawasan transit Stasiun

\begin{tabular}{llcc}
\multicolumn{4}{c}{ Cigombong } \\
\multicolumn{1}{c}{ Desa } & Kecamatan & Luas (ha) & \% \\
\hline Wates Jaya & Cigombong & 56.3 & 28.0 \\
Cigombong & Cigombong & 50.3 & 25.0 \\
Cisalada & Cigombong & 39.7 & 19.8 \\
Ciburuy & Cigombong & 34.0 & 16.9 \\
Tugu Jaya & Cigombong & 20.7 & 10.3 \\
\hline
\end{tabular}

Rekapitulasi hasil pengamatan indikator analisis di seluruh kawasan transit dijelaskan pada Tabel 14 dan keberagaman pemanfaatan ruang di setiap kawasan transit dijelaskan pada Gambar 2.

Tabel 14. Rekapitulasi hasil pengamatan indikator analisis di seluruh kawasan transit

\begin{tabular}{|c|c|c|c|c|c|c|c|c|c|}
\hline \multirow{2}{*}{$\begin{array}{c}\text { Kawasan } \\
\text { Transit }\end{array}$} & \multicolumn{9}{|c|}{ Indikator } \\
\hline & C1 & $\mathrm{C2}$ & C3 & C4 & C5 & C6 & C7 & C8 & C9 \\
\hline Sta. Cilebut & 2 & 4 menit & 4 & 80.8 & 143 & 5 & $90.8: 9.2$ & $\begin{array}{l}\text { Permukiman perkotaan } \\
\text { kepadatan tinggi }(100 \%)\end{array}$ & - \\
\hline $\begin{array}{l}\text { Sta. } \\
\text { Bojonggede }\end{array}$ & 2 & 4 menit & 4 & 90.6 & 168 & 6 & $93.3: 6.7$ & $\begin{array}{l}\text { Permukiman perkotaan } \\
\text { kepadatan tinggi }(100 \%)\end{array}$ & $\begin{array}{l}\text { Berdekatan } \\
\text { dengan PKWp } \\
\text { Cibinong }\end{array}$ \\
\hline Sta. Citayam & 2 & 4 menit & 4 & 86 & 180 & 5 & $94.6: 5.4$ & $\begin{array}{l}\text { Permukiman perkotaan } \\
\text { kepadatan tinggi }(100 \%)\end{array}$ & 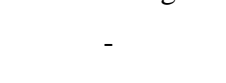 \\
\hline Sta. Cibinong & 1 & 52 menit & 4 & 81.5 & 155 & 6 & $73.9: 26.1$ & $\begin{array}{l}\text { Permukiman perkotaan } \\
\text { kepadatan tinggi }(100 \%)\end{array}$ & $\begin{array}{l}\text { PKWp Cibinong, } \\
\text { PPLk Cirimekar }\end{array}$ \\
\hline Sta. Nambo & 1 & $\begin{array}{l}1 \text { jam } 50 \\
\text { menit }\end{array}$ & 1.2 & 47.3 & 34 & 5 & $93: 7$ & Kawasan industri (52.7\%) & - \\
\hline $\begin{array}{l}\text { Sta. Parung } \\
\text { Panjang }\end{array}$ & 1 & 9 menit & 4 & 64.9 & 88 & 5 & $90: 10$ & $\begin{array}{l}\text { Permukiman perkotaan } \\
\text { kepadatan tinggi }(95.8 \%)\end{array}$ & - \\
\hline Sta. Tenjo & 1 & 11 menit & 4 & 29 & 16 & 4 & $95.5: 4.5$ & $\begin{array}{l}\text { Permukiman perkotaan } \\
\text { kepadatan tinggi }(100 \%)\end{array}$ & - \\
\hline Sta. Maseng & 1 & $\begin{array}{l}2 \text { jam } 27 \\
\text { menit }\end{array}$ & 3 & 24.2 & 33 & 5 & $87: 13$ & $\begin{array}{c}\text { Peruntukan lahan basah } \\
\qquad(44.2 \%)\end{array}$ & PKLp Caringin \\
\hline Sta. & 1 & 2 jam 33 & 3 & 42.1 & 58 & 5 & $84.7: 15.3$ & Permukiman & - \\
\hline
\end{tabular}




\begin{tabular}{cccccccccc}
\hline Kawasan & & & \multicolumn{7}{c}{ Indikator } \\
\cline { 2 - 8 } Transit & C1 & C2 & C3 & C4 & C5 & C6 & C7 & C8 & C9 \\
\hline Cigombong & & menit & & & & & & perkotaan kepadatan & sedang $(89.6 \%)$ \\
& & & & & & & & & \\
\hline
\end{tabular}

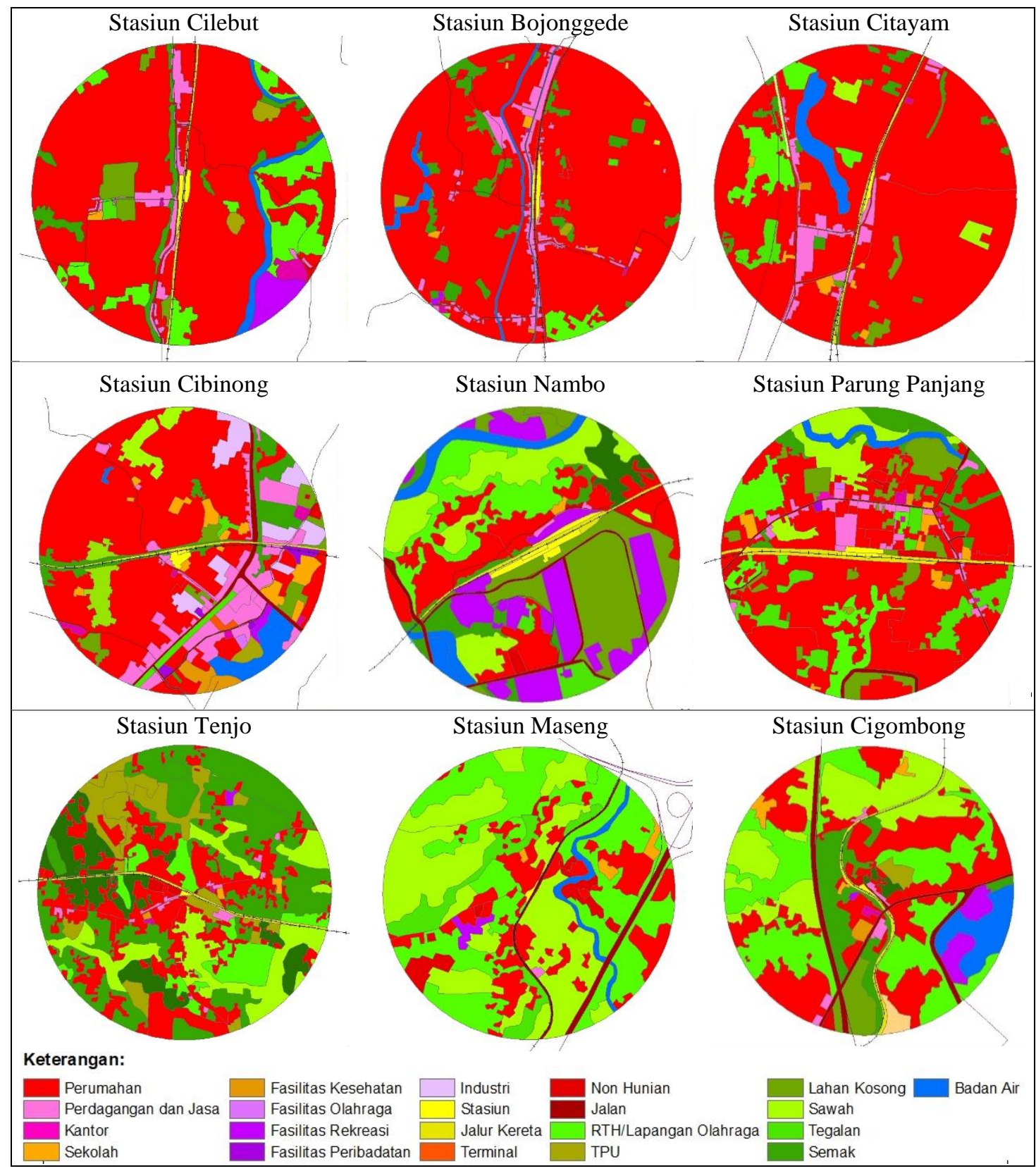

Gambar 2. Keragaman pemanfaatan ruang di setiap kawasan transit

\section{Lokasi Potensial TOD}

Hasil pengamatan terhadap indikator analisis di setiap kawasan transit kemudian diterjemahkan ke dalam skor sebagaimana ketentuan pada Tabel 1. Variabel analisis diberi bobot melalui metode AHP berdasarkan pendapat beberapa narasumber yang mewakili ahli perencanaan wilayah dan kota, ahli bidang transportasi dari Badan Pengelola Transportasi Jabodetabek (BPTJ), praktisi, konsultan perencana tata ruang, dan komuter. Pengumpulan data narasumber dilakukan dengan metode wawancara dan pengisian kuesioner AHP. Bobot setiap variabel kemudian dibagi rata ke masing-masing indikator analisis, kecuali pada variabel 
kebijakan tata ruang. Indikator kesesuaian peruntukan ruang diberi bobot lebih tinggi karena dinilai lebih penting dalam mewujudkan kawasan TOD dibandingkan dengan indikator lainnya pada variabel kebijakan tata ruang. Bobot variabel dan indikator analisis dijelaskan pada Tabel 15.

Tabel 15. Bobot variabel analisis TOPSIS

\begin{tabular}{|c|c|c|c|}
\hline Variabel & $\begin{array}{c}\text { Bobot } \\
(\%)\end{array}$ & Indikator & $\begin{array}{c}\text { Bobot } \\
(\%)\end{array}$ \\
\hline \multirow{2}{*}{ Transit } & \multirow{2}{*}{31} & Jumlah moda & 15.5 \\
\hline & & Headway & 15.5 \\
\hline \multirow{3}{*}{ Density } & \multirow{3}{*}{22} & KLB & 7.3 \\
\hline & & Tutupan lahan & 7.3 \\
\hline & & Kepadatan populasi & 7.3 \\
\hline \multirow{2}{*}{ Diversity } & \multirow{2}{*}{16} & $\begin{array}{l}\text { Jumlah jenis } \\
\text { pemanfaatan ruang }\end{array}$ & 8.0 \\
\hline & & $\begin{array}{l}\% \text { hunian: \% non } \\
\text { hunian }\end{array}$ & 8.0 \\
\hline \multirow{2}{*}{$\begin{array}{l}\text { Kebijakan } \\
\text { tata ruang }\end{array}$} & \multirow{2}{*}{31} & $\begin{array}{l}\text { Rencana kawasan } \\
\text { strategis }\end{array}$ & 14.0 \\
\hline & & $\begin{array}{l}\text { Kesesuaian } \\
\text { peruntukan ruang }\end{array}$ & 17.0 \\
\hline
\end{tabular}

Berdasarkan data hasil pengamatan di setiap kawasan transit kemudian dilakukan analisis TOPSIS di sembilan kawasan transit dengan tahapan sebagai berikut:

a. Menentukan kode wilayah untuk setiap kawasan transit

Tabel 16. Kode wilayah penelitian

\begin{tabular}{cl}
\hline Kode Wilayah & \multicolumn{1}{c}{ Kawasan Transit } \\
\hline A1 & Stasiun Cilebut \\
A2 & Stasiun Bojonggede \\
A3 & Stasiun Citayam \\
A4 & Stasiun Cibinong \\
A5 & Stasiun Nambo \\
A6 & Stasiun Parung Panjang \\
A7 & Stasiun Tenjo \\
A8 & Stasiun Maseng \\
A9 & Stasiun Cigombong \\
\hline
\end{tabular}

b. Melakukan konversi data analisis hasil pengamatan menjadi skor sesuai dengan ketentuan pada Tabel 1. Data hasil perhitungan TOPSIS dijelaskan pada Tabel 17 sampai 21.

Tabel 17. Matriks data penelitian yang telah dikonversi

\begin{tabular}{cccccccccc}
\hline \multirow{2}{*}{ Wilayah } & \multicolumn{10}{c}{ Indikator } \\
\cline { 2 - 10 } & C1 & C2 & C3 & C4 & C5 & C6 & C7 & C8 & C9 \\
\hline A1 & 2 & 3 & 3 & 3 & 1 & 3 & 0 & 0 & 3 \\
A2 & 2 & 3 & 3 & 3 & 2 & 3 & 0 & 1 & 3 \\
A3 & 2 & 3 & 3 & 3 & 2 & 3 & 0 & 0 & 3 \\
A4 & 1 & 0 & 3 & 3 & 2 & 3 & 1 & 3 & 3 \\
A5 & 1 & 0 & 1 & 2 & 0 & 3 & 0 & 0 & 0 \\
A6 & 1 & 2 & 3 & 3 & 1 & 3 & 0 & 0 & 3 \\
A7 & 1 & 2 & 3 & 2 & 0 & 2 & 0 & 0 & 3 \\
A8 & 1 & 0 & 2 & 1 & 0 & 3 & 0 & 2 & 0 \\
A9 & 1 & 0 & 2 & 2 & 1 & 3 & 0 & 0 & 2 \\
\hline
\end{tabular}

Tabel 18. Matriks keputusan yang dinormalisasi

\begin{tabular}{cccccccccc}
\hline \multirow{2}{*}{ Wilayah } & \multicolumn{10}{c}{ Indikator } \\
\cline { 2 - 10 } & C1 & C2 & C3 & C4 & C5 & C6 & C7 & C8 & C9 \\
\hline A1 & 0.471 & 0.507 & 0.378 & 0.394 & 0.258 & 0.344 & 0.000 & 0.000 & 0.394 \\
A2 & 0.471 & 0.507 & 0.378 & 0.394 & 0.516 & 0.344 & 0.000 & 0.267 & 0.394 \\
A3 & 0.471 & 0.507 & 0.378 & 0.394 & 0.516 & 0.344 & 0.000 & 0.000 & 0.394 \\
A4 & 0.236 & 0.000 & 0.378 & 0.394 & 0.516 & 0.344 & 1.000 & 0.802 & 0.394 \\
A5 & 0.236 & 0.000 & 0.126 & 0.263 & 0.000 & 0.344 & 0.000 & 0.000 & 0.000 \\
A6 & 0.236 & 0.338 & 0.378 & 0.394 & 0.258 & 0.344 & 0.000 & 0.000 & 0.394 \\
A7 & 0.236 & 0.338 & 0.378 & 0.263 & 0.000 & 0.229 & 0.000 & 0.000 & 0.394 \\
A8 & 0.236 & 0.000 & 0.252 & 0.131 & 0.000 & 0.344 & 0.000 & 0.535 & 0.000
\end{tabular}




\begin{tabular}{cccccccccc}
\hline \multirow{2}{*}{ Wilayah } & \multicolumn{10}{c}{ Indikator } \\
\cline { 2 - 11 } & C1 & C2 & C3 & C4 & C5 & C6 & C7 & C8 & C9 \\
\hline A9 & 0.236 & 0.000 & 0.252 & 0.263 & 0.258 & 0.344 & 0.000 & 0.000 & 0.263 \\
Sqrt & 4.243 & 5.916 & 7.937 & 7.616 & 3.873 & 8.718 & 1.000 & 3.742 & 7.616 \\
\hline
\end{tabular}

Tabel 19. Menentukan solusi ideal positif dan solusi ideal negatif

\begin{tabular}{cccccccccc}
\hline Weight (bobot) & $\mathbf{0 . 1 5 5}$ & $\mathbf{0 . 1 5 5}$ & $\mathbf{0 . 0 7 3}$ & $\mathbf{0 . 0 7 3}$ & $\mathbf{0 . 0 7 3}$ & $\mathbf{0 . 0 8}$ & $\mathbf{0 . 0 8}$ & $\mathbf{0 . 1 4}$ & $\mathbf{0 . 1 7}$ \\
\hline Wilayah & $\mathbf{C 1}$ & $\mathbf{C 2}$ & $\mathbf{C 3}$ & $\mathbf{C 4}$ & $\mathbf{C 5}$ & $\mathbf{C 6}$ & $\mathbf{C 7}$ & $\mathbf{C 8}$ & $\mathbf{C 1 0}$ \\
\hline A1 & 0.0731 & 0.0786 & 0.0277 & 0.0289 & 0.0189 & 0.0275 & 0.0000 & 0.0000 & 0.0670 \\
A2 & 0.0731 & 0.0786 & 0.0277 & 0.0289 & 0.0379 & 0.0275 & 0.0000 & 0.0374 & 0.0670 \\
A3 & 0.0731 & 0.0786 & 0.0277 & 0.0289 & 0.0379 & 0.0275 & 0.0000 & 0.0000 & 0.0670 \\
A4 & 0.0365 & 0.0000 & 0.0277 & 0.0289 & 0.0379 & 0.0275 & 0.0800 & 0.1122 & 0.0670 \\
A5 & 0.0365 & 0.0000 & 0.0092 & 0.0193 & 0.0000 & 0.0275 & 0.0000 & 0.0000 & 0.0000 \\
A6 & 0.0365 & 0.0524 & 0.0277 & 0.0289 & 0.0189 & 0.0275 & 0.0000 & 0.0000 & 0.0670 \\
A7 & 0.0365 & 0.0524 & 0.0277 & 0.0193 & 0.0000 & 0.0184 & 0.0000 & 0.0000 & 0.0670 \\
A8 & 0.0365 & 0.0000 & 0.0185 & 0.0096 & 0.0000 & 0.0275 & 0.0000 & 0.0748 & 0.0000 \\
A9 & 0.0365 & 0.0000 & 0.0185 & 0.0193 & 0.0189 & 0.0275 & 0.0000 & 0.0000 & 0.0446 \\
\hline Max Ideal & 0.0731 & 0.0786 & 0.0277 & 0.0289 & 0.0379 & 0.0275 & 0.0800 & 0.1122 & 0.0670 \\
Min Ideal & 0.0365 & 0.0000 & 0.0092 & 0.0096 & 0.0000 & 0.0184 & 0.0000 & 0.0000 & 0.0000 \\
\hline
\end{tabular}

Tabel 20. Menghitung ukuran pemisahan dan jarak kedekatan relatif dengan solusi ideal

\begin{tabular}{cccc}
\hline Wilayah & di+ & di- & Si \\
\hline A1 & 0.1391 & 0.1147 & 0.4518 \\
A2 & 0.1095 & 0.1250 & 0.5330 \\
A3 & 0.1378 & 0.1193 & 0.4639 \\
A4 & 0.0867 & 0.1604 & 0.6491 \\
A5 & 0.1813 & 0.0133 & 0.0684 \\
A6 & 0.1462 & 0.0916 & 0.3851 \\
A7 & 0.1504 & 0.0875 & 0.3679 \\
A8 & 0.1473 & 0.0760 & 0.3403 \\
A9 & 0.1660 & 0.0511 & 0.2355 \\
\hline
\end{tabular}

Table 21. Menyusun urutan prioritas keputusan

\begin{tabular}{clc}
\hline $\begin{array}{c}\text { Urutan } \\
\text { prioritas }\end{array}$ & Kawasan transit & Nilai Si \\
\hline 1 & Sta. Cibinong & 0.6491 \\
2 & Sta. Bojonggede & 0.5330 \\
3 & Sta. Citayam & 0.4639 \\
4 & Sta. Cilebut & 0.4518 \\
5 & Sta. Parung Panjang & 0.3851 \\
6 & Sta. Tenjo & 0.3679 \\
7 & Sta. Cigombong & 0.3403 \\
8 & Sta. Maseng & 0.2355 \\
9 & Sta. Nambo & 0.0684 \\
\hline
\end{tabular}

Berdasarkan perhitungan diperoleh hasil kawasan transit yang menempati urutan prioritas tiga teratas dan potensial dikembangkan menjadi kawasan TOD adalah kawasan transit Stasiun Cibinong, Stasiun Bojonggede, dan Stasiun Citayam.

Berdasarkan hasil perhitungan TOPSIS kemudian kawasan transit diklasifikasikan menjadi tiga kategori sebagaimana dijelaskan pada Tabel 22.

Tabel 22. Tipologi kawasan transit

\begin{tabular}{|c|c|c|}
\hline Kategori & $\begin{array}{l}\text { Tingkat } \\
\text { potensi }\end{array}$ & Kawasan transit \\
\hline I & Tinggi & $\begin{array}{c}\text { Sta. Cibinong, Sta. } \\
\text { Bojonggede, Sta. Citayam } \\
\text { Sta. Cilebut }\end{array}$ \\
\hline II & Sedang & $\begin{array}{c}\text { Sta. Parung Panjang, } \\
\text { Sta. Tenjo }\end{array}$ \\
\hline III & Rendah & $\begin{array}{c}\text { Sta. Maseng, Sta. } \\
\text { Cigombong, Sta. Nambo }\end{array}$ \\
\hline
\end{tabular}

Kategori I merupakan kawasan transit yang paling potensial dikembangkan menjadi kawasan TOD, kategori II yang memiliki tingkat potensi sedang dan kategori III adalah 
kawasan transit yang tidak potensial dikembangkan menjadi kawasan TOD.

\section{KESIMPULAN DAN REKOMENDASI}

Hasil penelitian terhadap potensi pengembangan kawasan berbasis TOD di Kabupaten Bogor menunjukkan bahwa terdapat kawasan transit yang berpotensi tinggi, sedang, dan rendah. Berdasarkan tipologi kawasan transit kemudian dirumuskan rekomendasi pemanfaatan ruang berbasiskan konsep TOD agar prasyarat TOD yang ideal dapat terpenuhi.

\section{Kawasan Transit I}

Kawasan ini merupakan kategori "potensial" untuk dikembangkan berbasiskan konsep TOD dengan rekomendasi pemanfaatan ruang sebagai berikut:

a. Diperlukan peningkatan dan penyediaan layanan transportasi pengumpan (feeder) untuk mendukung pergerakan penumpang.

b. Pembangunan mulai diarahkan pada pembangunan vertikal karena walaupun kawasan ini sudah memiliki kepadatan lahan terbangun yang tinggi (density) namun masih didominasi oleh kepadatan horizontal.

c. Diperlukan peningkatan ketersediaan fasilitas pendukung permukiman untuk meningkatkan keberagaman pemanfaatan ruang (diversity) pada kawasan yang masih didominasi oleh fungsi hunian. Persentase fungsi non hunian tertinggi ditemukan di kawasan transit Stasiun Cibinong.

d. Perlu penyediaan jalur pedestrian dan pesepeda yang baik untuk mendukung mobilitas non-motorized.

e. Di kawasan transit Stasiun Cibinong diperlukan peningkatan frekuensi layanan transit (headway) untuk meningkatkan mobilitas penduduk karena headway angkutan KRL di kawasan ini masih tergolong rendah yaitu rata-rata 52 menit.

Kawasan ini paling berpotensi dikembangkan dengan konsep TOD karena memiliki kepadatan kawasan dan populasi yang tinggi. Sehingga sesuai dengan prinsip TOD yang bertujuan untuk mewujudkan kawasan yang padat dan kompak (Suzuki et al., 2013). Kepadatan yang tinggi diperlukan untuk mendukung pelayanan kereta api. Sesuai dengan pernyataan "Mass transit needs mass" (Bernick \& Cervero 1997). Tanpa kepadatan yang cukup tinggi maka stasiun transit akan gagal dalam menarik penumpang. Choerunnisa dan Dirgahayani (2020) dalam penelitiannya menemukan adanya korelasi positif antara penumpang SAUM dengan guna lahan di sekitar stasiun. Namun demikian pemenuhan prinsip diversity dan desain kawasan yang ramah pejalan kaki dan pesepeda masih menjadi tantangan besar dalam perwujudan TOD di kawasan ini. Begitu pula dalam pemenuhan angkutan pengumpan (feeder) di sekitar stasiun. Berdasarkan karakteristiknya, tipologi TOD yang dapat dikembangkan di kawasan ini adalah tipe TOD-Lingkungan. Karena tingkat keragaman pemanfaatan ruang di kawasan ini masih didominasi oleh fungsi hunian dan karakter pengembangan kawasan sebagai pusat aktivitas ekonomi lokal dan komunitas lokal.

\section{Kawasan Transit II}

Kawasan ini merupakan kategori "cukup potensial" dikembangkan berbasiskan konsep TOD dengan rekomendasi pemanfaatan ruang sebagai berikut:

a. Diperlukan peningkatan dan penyediaan layanan transportasi pengumpan (feeder) untuk mendukung pergerakan penumpang.

b. Diperlukan peningkatan ketersediaan fasilitas pendukung permukiman untuk meningkatkan keberagaman pemanfaatan ruang (diversity) karena kawasan ini masih didominasi oleh fungsi hunian serta untuk mendukung aktivitas penduduknya karena ketersediaan fasilitas di kawasan ini masih tergolong rendah.

c. Perlu penyediaan jalur pedestrian dan pesepeda yang baik untuk mendukung mobilitas non-motorized.

Frekuensi layanan transit yang tinggi mendukung kawasan ini dapat dikembangkan dengan konsep TOD. Dalam kebijakan RTRW juga ditetapkan kawasan ini kedepannya 
diarahkan sebagai kawasan permukiman perkotaan kepadatan tinggi. Meskipun saat ini kepadatan populasinya masih tergolong sedangrendah, namun dengan pengembangan yang tepat kawasan ini tentunya mampu menarik penduduk untuk menciptakan densitas yang tinggi. Salah satunya adalah dengan pemenuhan ketersediaan fasilitas dan menciptakan lingkungan permukiman yang nyaman dan berkelanjutan dengan pengembangan konsep TOD. Dengan persentase tutupan lahan yang tergolong rendah pada tahun 2020 maka kawasan ini berpotensi lebih mudah dikembangkan dikarenakan masih tersedia banyak lahan kosong yaitu seluas 64.8 ha di kawasan transit Stasiun Parung Panjang dan seluas 144.3 ha di kawasan transit Stasiun Tenjo.

\section{Kawasan Transit III}

Kawasan ini merupakan kategori "tidak potensial" dikembangkan berbasiskan konsep TOD. Frekuensi layanan transit yang masih rendah, kepadatan populasi yang rendah, serta ketidaksesuaian peruntukan ruang dalam RTRW menjadikan kawasan transit Stasiun Cigombong, Stasiun Maseng, dan Nambo tidak berpotensi dikembangkan dengan konsep TOD.

Persentase tutupan lahan yang tinggi pada kawasan transit kategori I yaitu sebesar $>80 \%$ dari total wilayah mengindikasikan tingginya luas lahan terbangun di kawasan ini. Ditambah dengan kepadatan populasi yang tinggi menunjukkan bahwa kawasan ini mengalami perkembangan yang pesat. Sejalan dengan penelitian lainnya yang menunjukkan bahwa perkembangan wilayah peri-urban yang berada di pinggiran kota berbanding lurus dengan variabel aksesibilitas dan ketersediaan fasilitas (Putra \& Pradoto, 2016; Rizki et al., 2018). Perkembangan kawasan yang pesat perlu diimbangi dengan keberagaman pemanfaatan ruang agar penyediaan fasilitas penduduk terpenuhi dengan baik. Selain dapat meningkatkan hierarki wilayah, ketersediaan fasilitas juga menjadi daya tarik bagi seseorang untuk mendatangi atau hidup berkelompok di kawasan tersebut (Panuju \& Rustiadi, 2013;
Utari, 2015; Fuadina et al., 2018). Kelengkapan fasilitas di kawasan yang padat penduduk yang mudah dijangkau dari perumahan dapat menciptakan pemusatan aktivitas sehingga mobilitas dengan penggunaan kendaraan pribadi dapat perlahan dikurangi. Senada dengan semangat konsep TOD yang ingin menciptakan mobilitas berkelanjutan dalam suatu kawasan campuran yang padat, kompak dan terpusat yang terintegrasi dengan angkutan umum massal sehingga dapat mendorong pergerakan non-motorized di kawasan transit (Suzuki et al., 2013).

\section{UCAPAN TERIMA KASIH}

Ucapan terima kasih disampaikan kepada Beasiswa Pusbindiklatren Bappenas yang telah mendukung dana penelitian.

\section{DAFTAR PUSTAKA}

Arif, F. N. \& Manullang, O. R. (2017). Kesesuaian Tata Guna Lahan Terhadap Penerapan Konsep Transit Oriented Development (TOD) di Kota Semarang. Jurnal Pembangunan Wilayah Dan Kota, 13(3), 301-311. https://doi.org/10.14710/mkmi.\%v.\%i.1-14

Arsyad, M. A. \& Handayeni, K. D. M. E. (2018). Analisa Kesesuaian Kawasan Transit Blok M Jakarta terhadap Kriteria Konsep TOD (Transit Oriented Development). Jurnal Teknis ITS, 7(1), 001-007. https://doi.org/10.36870/insight.v1i1.8

Ayuningtias, S. H. \& Karmilah, M. (2019). Penerapan Transit Oriented Development (TOD) sebagai Upaya Mewujudkan Transportasi yang Berkelanjutan. Pondasi, 24(1),45.https://doi.org/10.30659/pondasi.v24i 1.4996

Balioti, V., Tzimopoulos, C., \& Evangelides, C. (2018). Multi-Criteria Decision Making Using TOPSIS Method Under Fuzzy Environment. Application in Spillway Selection. Proceedings, 2(11), 637. https://doi.org/10.3390/proceedings2110637

Bernick, M. \& Cervero, R. (1997). Transit Villages in the $21^{\text {st }}$ Century. New York: McGraw-Hill. 
Calthorpe, P. (1993). "The Next American Metropolis: Ecology, Community and The American Dreams." In New York: Pricenton Architectural Press. https://doi.org/10.4324/9780203501627-15

Cervero, R. \& Kockelman, K. (1997). Travel Demand and The 3Ds: Density, Diversity, and Design. Transportation Research Part D: Transport and Environment, 2(3), 199-219. https://doi.org/10.1016/S1361-9209(97)00009. 6

Choerunnisa, D. N. \& Dirgahayani, P., (2020). Pengembangan Model Perkiraan Penumpang SAUM sebagai Dampak Penggunaan Lahan pada Kawasan Berbasis Transit (Studi Kasus: LRT Koridor III Kota Bandung). Jurnal Pengembangan Kota, 8(1), 48 - 57. DOI: 10.14710/jpk.8.1.48-57

Dirgahayani, P. \& Choerunnisa, D. N., (2019). Development of Methodology to Evaluate TOD Feasibility in Built-up Environment (Case Study: Jakarta and Bandung, Indonesia). IOP Conference Series: Earth and Environmental Series, 158(1). doi:10.1088/1755-1315/158/1/012019

Ewing, R. \& Cervero, R. (2010). Travel and the Built-up environment: A Meta Analysis. J. of the American Planning Association.

Fuadina, L. N., Rustiadi, E., \& Pravitasari, A. E. (2018). Perubahan Penggunaan Lahan dan Keragaman Spasial Faktor-Faktor yang Mempengaruhi Pertumbuhan Perkotaan di Metropolitan Bandung. Tesis. Institut Pertanian Bogor.

Guerra, E., Cervero, R., \& Tischler, D. (2012). HalfMile Circle: Does It Best Represent Transit Station Catchments? Transportation Research Record, 2276(1), 101-109.

ITDP. (2017). TOD Standard. TOD Standard, 3, 61. www.ITDP.org

Jati, D. K., Nurhadi, K., \& Rini, E. F. (2017). Kesesuaian Kawasan Transit di Kota Surakarta Berdasarkan Konsep Transit Oriented Development. Region: Jurnal Pembangunan Wilayah Dan Perencanaan Partisipatif, 12(2), 168.

https://doi.org/10.20961/region.v12i2.12542
Menteri Agraria dan Tata Ruang/Kepala Badan Pertanahan Nasional. 2017. Peraturan Menteri Agraria dan Tata Ruang/Kepala BPN Nomor 16 Tahun 2017 tentang Pedoman Pengembangan Kawasan Berorientasi Transit. Jakarta (ID): Kementerian Agraria dan Tata Ruang/BPN

Najib, W. Z. W. M., Norzailawati, M. N., \& Hamsa, A. A. K. (2020). Transit-Oriented Development (TOD) Planning Analysis by Integrating Geographic Information System (GIS) Approach. Journal of Architecture, Planning \& Construction Management, 10(1), $1-15$.

Octarino, C. N. (2016). Pengembangan Kawasan Permukiman Suburban Berbasis Transit Oriented Development (TOD). Atrium-Jurnal Arsitektur, 2(2), 135-144.

Panuju, D. R. \& Rustiadi, E. (2013). Teknik Analisis Perencanaan Pengembangan Wilayah. Bogor: Lab. Pengembangan Wilayah, Departemen Ilmu Tanah dan Sumberdaya Lahan, Institut Pertanian Bogor.

Presiden Republik Indonesia. (2020). Peraturan Presiden Nomor 60 Tahun 2020 tentang Rencana Tata Ruang Kawasan Perkotaan Jakarta, Bogor, Depok, Tangerang, Bekasi, Puncak, dan Cianjur. Jakarta (ID): Sekretariat Kabinet RI.

Priadmaja, A. P., Anisa, \& Prayogi, L. (2017). Penerapan Konsep Transit Oriented Development (TOD) pada Penataan Kawasan di Kota Tangerang. PURWARUPA Jurnal Arsitektur, 1(2), 53-60.

Purwanto, D. (2015). Pengelolaan Transportasi Berwawasan Lingkungan Sebagai Dampak Perkembangan Perkotaan Tak Terkendali (Studi Kasus Kota Semarang). Media Komunikasi Teknik Sipil, 20(1), 93-101. https://doi.org/10.14710/mkts.v20i1.9250

Putra, D. R. \& Pradoto, W. (2016). Pola dan Faktor Perkembangan Pemanfaatan Lahan di Kecamatan Mranggen, Kabupaten Demak. Jurnal Pengembangan Kota, 4(1), 67. https://doi.org/10.14710/jpk.4.1.67-75

Rizki, D. A., Rustiadi, E., \& Soma, S. (2018). Penentuan Pusat-pusat Kegiatan Baru sebagai Alternatif untuk Mengurangi Kemacetan Kota Bogor. Journal of Regional and Rural Development Planning, 1(3), 287. https://doi.org/10.29244/jp2wd.2017.1.3.287297 
Roy, M. A. C., Rusdiana, O., \& Ichwandi, I. (2017).

Dinamika Perubahan dan Kebijakan

Pemanfaatan Ruang di Kabupaten Bogor, Provinsi Jawa Barat. Journal of Env. Engineering and Waste Management, 2(2), 60-68.

Ruhukail, S. R. \& Oktavia, P. (2017). Lokasi Potensial Pengembangan Kawasan Berbasis Konsep TOD (Transit-Oriented Development) di Kawasan Perkotaan Kabupaten Bekasi. Jurnal Perencanaan Wilayah Dan Kota ITSB, $1-12$.

Sumajouw, J., Sompie, B., \& Timboeleng, J. (2013). Analisis Dampak Lalu Lintas (Andalalin) Kawasan Kampus Universitas Sam Ratulangi. Jurnal Ilmiah Media Engineering, 3(2), 98676.

Suzuki, H., Cervero, R., \& Luchi, K. (2013). Transform Cities with Transit: Transit and Land_use Integration for Sustainable Urban Development. The World Bank: Washington DC.

TCRP (Transit Cooperative Research Program). (2002). Transit-Oriented Development and Joint Development in the United States: A Literature Review. Washington DC: Transportation Research. (http://online pubs.trb.org/onlinepubs/tcrp/tcrp_rrd_52.pdf)

TCRPC (Treasure Coast Regional Planning Council). (2012). Florida TOD Guidebook. Tallahassee: Florida Department of Transportation

Utari, M. E. S. (2015). Analisis Sistem Pusat Pelayanan Permukiman di Kota Yogyakarta Tahun 2014. Journal of Economics and Policy,8(1). https://doi.org/10.15294/jejak.v8i1.3856

Widyahari, N. L. A. \& Indradjati, P. N. (2015). The Potential of Transit-Oriented Development (TOD) and its Opportunity in Bandung Metropolitan Area. Procedia Environmental Sciences, 28(SustaiN 2014), 474-482. https://doi.org/10.1016/j.proenv.2015.07.057 